УДК 4414

\title{
АКТУАЛЬНЫЕ ВОПРОСЫ РЕАЛИЗАЦИИ ДОГОВОРА ФРАНЧАЙЗИНГА
}

\author{
Галынина Лидия Ивановна \\ студентка
}

Научный руководитель: Бибиков Александр Иванович

д.ю.н., профессор

ФГБОУ ВО «Ивановский государственный университет»

\begin{abstract}
Аннотация: В статье предпринята попытка изложить этапы развития такого феномена, как франчайзинг, указать исторические аспекты его развития и некоторые особенности, а также выявить ошибки при заключении договора коммерческой концессии. Определить роль франчайзинга в современном бизнесе и гражданско-правовых отношениях между участниками.

Ключевые слова: Гражданское право, франчайзинг, франшиза, бизнес, коммерческая концессия.
\end{abstract}

\section{CURRENT ISSUES OF IMPLEMENTATION OF THE FRANCHISING AGREEMENT}

Galynina Lidiya Ivanovna Bibikov Alexander Ivanovich

\begin{abstract}
The article attempts to outline the stages of development of either phenomenon as franchising, to indicate the historical aspects of its development and some features, also to identify mistakes when concluding a commercial concession agreement. Determine the role of franchising in modern business and civil law relations between participants.
\end{abstract}

Key words: Civil law, franchising, franchise, business, commercial concession.

Популярность такого феномена, как франшиза, с каждым годом становится более очевидной. В связи с этим справедливо утверждать, что 
основой успеха будущего бизнеса станет юридически верно составленный договор франчайзинга.

Слово «франчайзинг» (фр. francise), означает «льгота, привилегия, освобождение от налога, взноса» [1, с.12]. Его корни ушли в средние века. В средневековой Англии такое право, как сбор налогов на конкретной территории в обмен на определенные услуги предоставлялось королем для знати.

В начале XIX века в Великобритании была введена система «связанных домов», властями предоставлялось право на торговлю спиртными напитками только владельцам постоялых дворов по специальной лицензии. [2, с.552].

Для обеспечения справедливых франчайзинговых правоотношений были созданы такие организации, как: Международная Ассоциация Франчайзинга (1960 год), Европейская Ассоциация Франчайзинга (1972 год).

В России франчайзинг начал развиваться с 1990-х г.г. Первым участником международной франчайзинговой ассоциации стала компания «Дока» г. Тольятти. Теперь на территории страны успешно действуют такие франчайзинговые сети российских фирм, как «Русское бистро», «Русская трапеза» «Хлебное дело», «1 С», «Модный трикотаж» и порядка 30 известных иностранных брэндов, которыми владеют такие компании, как «Buskin Robbins», «Xerox», «Kodak», «Benetton», «Pizza Hut», «Subway» и многие другие [3, с. 47].

По темпам развития франчайзинга Россия входит в число мировых лидеров. Согласно направлениям развития Российской Ассоциации франчайзинга, к 2025 году планируется увеличить количество точек, открытых по франшизе до 200 тыс., что повысит количество рабочих мест с существующих 500 тыс. до 2 млн. в точках, открытых по такой форме международного сотрудничеств [4, с.113].

Договор коммерческой концессии обладает следующими отличительными чертами:

- Обязательным объектом договора являются фирменное наименование и охраняемая коммерческая информация;

- Сторонами договора коммерческой концессии выступают правообладатель и пользователь. И пользователями могут быть только коммерческие организации и индивидуальные предприниматели;

- Договор коммерческой концессии должен быть заключен в письменной форме и зарегистрирован в органе, в котором зарегистрирован правообладатель. 
- Возмездный характер договора. [5, с. 27].

Важно отметить, что термины «франчайзи» и «франчайзер» не фигурируют в российской юриспруденции: это зарубежные обозначения.

В теории гражданского права является важным определение правовой природы указанного соглашения: Договор коммерческой концессии является самостоятельным видом соглашения, и не относится к смешанным договорам. Предмет данного договора обладает комплексным характером, но к нему относится совокупность принадлежащих правообладателю исключительных прав, ранее указанных.

На данном этапе развития франчайзинга выявлены следующие распространенные ошибки:

1) У продавца нет товарного знака, который зарегистрирован по правилам законодательства, или же он вообще не является его собственником. Необходимую информацию о товарном знаке можно получить из реестров, которые находятся на сайте rospatent.gov.ru. Так же следует потребовать копию свидетельства о регистрации знака, или соглашение могут признать недействительным;

2) Нет оригинала подписанного договора;

3) Неверное использование юридических терминов;

4) Оплата сделки до регистрации договора в Роспатенте. В таком случае, как правило, может возникнуть двоякая ситуация: Сделку могут признать несостоявшейся по причине отсутствия данных в соответствующей базе регистрационного органа, но если рассмотреть указанную ситуацию с противоположной стороны, то логично предположить, что покупатель мог уже отправить первый транш франчайзеру. И франчайзер в праве при желании оспорить сделку, однако если клиента будет не устраивать качество товара, то собственник сможет уйти от субсидиарной ответственности, указав, что договор коммерческой концессии был недействительным;

5) Предоставление списка поставщиков с требованием закупать товар у них, чтобы соответствовать стандартам франчайзера.

6) Целесообразно подобрать те варианты, которые полностью соответствуют стандартам обоих сторон, предложить закрепить это в договоре;

7) Ограничение в выборе помещений; Следует зафиксировать в договоре франчайзинга, что сами вправе выбрать помещение для работы;

8) Не указана территория, на которой можно вести предпринимательскую деятельность; 
9) Не прописаны размеры штрафов, пеней, отступных, что влечет за собой конкретное действие или бездействие каждого из участников;

10) Нет конкретных сроков действия договора франшизы;

11) Доверие к прогнозам франчайзинга с экономической позиции; Следует самостоятельно проанализировать перспективность определенной франшизы в целях получения прибыли от бизнеса.

Таким образом, франчайзинг является эффективным механизмом развития юридически-узаконенного процесса покупки возможности ведения бизнеса, но некоторые указанные в исследовании ситуации, которые возникали на практике, нуждались в четкости и большей ясности, тем самым можем предложить способ дальнейшего совершенствования и правового регулирования: Урегулировать в ГК РФ вопрос об удовлетворении требований при признании договоров коммерческой концессии недействительными.

Например, Арбитражный суд города Севастополя в феврале 2016 года решил исковые требования удовлетворить частично. ООО „ФинситиСимферополь” обратилось с исковым заявлением к ООО „Эф-Си Хаус”, в котором просило суд: признать недействительным договор франчайзинга (коммерческой концессии), признать недействительным лицензионный договор, применить последствия недействительности договора, возместить причиненные убытки, оплатить предоставленные услуги, взыскать проценты, также взыскать судебные издержки.

В данной правовой ситуации Суд признал недействительным договор франчайзинга (коммерческой концессии) и лицензионный договор в виду отсутствия государственной регистрации.

При данном решении возникали следующие вопросы: Если определенные права по договору франчайзинга передавались, хотя договор и не был зарегистрирован, должен ли он быть признан недействительным? А также в праве ли Истец заявлять другие требования при обстоятельствах, ранее указанных.

Хотя в г. 54 ГК РФ подробно уточнены вопросы, которые связаны с коммерческой концессией, в сфере правового регулирования франчайзинга обнаружился ряд вопросов, требующих уточнений. 


\section{Список литературы}

1. Рыкова И.В. Франчайзинг: новые технологии, методология, договоры // Современная экономика и право. - М.: Современная экономика и право. 2000. - $224 \mathrm{c}$.

2. Бабченко В.В. Франчайзинг как форма активизации предпринимательской деятельности // Научное сообщество студентов: Междисциплинарные исследования: сб. ст. по мат. I междунар. студ. науч.практ. конф. 2020. — № 1. - С. 552-556.

3. Шулус А.А., Быченко Н.Л. Франчайзинговые формы предпринимательства (объективные основы, противоречия, принципы господдержки) // Российский экономический журнал. - 1998. - №1. С. 44-47.

4. Бударина Н.А., Кириллова А.Н. Тенденции франчайзинга в современной России // Международный журнал гуманитарных и естественных наук. - 2020. - Номер: 9-1 (48). - С. 113-115.

5. В.Т. Батычко Гражданское право (Часть II) в вопросах и ответах. Краткий конспект лекций. - Таганрог.: ТТИ ЮФУ. — 2008. 36 с. 